\title{
Hubungan Usia dan Paritas Terhadap Kejadian Pre Eklampsia di RSD Balung Jember
}

\author{
Yuningsih \\ STIKES dr. Soebandi Jember, yunayyanbahari3@gmail.com
}

\begin{abstract}
ABSTRAK
Salah satu penyumbang Angka Kematian Ibu dan Bayi adalah kejadian Preeklampsia yang terjadi dalam masa kehamilan. Penyebab dari Preeklampsia sampai saat ini masih belum diketahui penyebabnya, tetapi ada dugaan bahwa faktor usia dan paritas merupakan salah satu pemicu terjadinya kejadian tersebut. Wanita usia subur yang nullipara dengan usia yang ekstrim dibawah usia kurang dari 20 tahun dan wanita dengan usia lebih dari 35 tahun paling banyak didapati mengalami Preeklampsia.Tujuan dari penelitian ini adalah untuk menyelidiki apakah ada pengaruh antara usia dan paritas terhadap kejadian preeklampsia. Desain pada penelitian ini adalah analitik dengan pendekatan cross sectional. Populasinya seluruh Ibu bersalin di ruang bersalin RSD Balung Jember sebesar 3594 pada tahun 2019. Jumlah sampel tersebut yang diambil menggunakan non random sampling dengan cara purposive sampling akhitnya didapatkan sebesar 97 responden. Pada penelitian ini yang menjadi variabel bebas adalah usia dan paritas ibu, sementara variabel terikatnya adalah kejadian preeklampsia. Instrumen yang digunakan adalah rekam medis. Data diolah dengan proses penyuntingan, pengkodean, processing dan cleaning. Data dianalisis menggunakan dengan regresi logistik berganda. Hasil uji chi-square untuk variable usia didapatkan nilai pearson chi-square adalah 0,019 dan nilai $p=0,000<0,05$ dari hasil tersebut Ho ditolak, dan variable paritas nilai pearson chi-square adalah 0,019 dan nilai $p=0,000<0,05$ dari hasil tersebut Ho ditolak. Kesimpulannya ada hubungan usia terhadap preeklampsia, dan ada hubungan juga paritas terhadap preeklampsia.
\end{abstract}

Kata kunci : Usia, paritas, preeklampsia

\begin{abstract}
One of the contributors to maternal and infant mortality is the incidence of preeclampsia that occurs during pregnancy. The cause of preeclampsia is still unknown, but it is suspected that age and parity are one of the triggers for this occurrence. Women of childbearing age who are nulliparous with extreme age under the age of less than 20 years and women with the age of more than 35 years are most commonly found to have preeclampsia. The design in this study is analytic with a cross sectional approach. The population of all mothers giving birth in the delivery room of RSD Balung Jember was 3594 in 2019. The number of samples taken using non-random sampling by purposive sampling was finally obtained by 97 respondents. In this study, the independent variables were maternal age and parity, while the dependent variable was the incidence of preeclampsia. The instrument used is medical records. The data is processed by editing, coding, processing and cleaning processes. Data were analyzed using multiple logistic regression. The results of the chi-square test for the age variable obtained that the Pearson chi-square value was 0.019 and the $p$ value $=0.000<0.05$ from these results Ho was rejected, and the parity variable the Pearson chisquare value was 0.019 and the $p$ value $=0.000<0.05$ from these results Ho is rejected. In conclusion, there is a relationship between age and preeclampsia, and there is a relationship between parity and preeclampsia.
\end{abstract}

Key words: Age, parity, preeclampsia

*Korespondensi Author: Yuningsih, SST., M.Keb, STIKES dr. Soebandi, yunayyanbahari3@gmail.com, 085649290232

\section{PENDAHULUAN}

Kematian maternal adalah tolok ukur kemajuan dan keberhasilan suatu bangsa sebagai upaya kesehatan ibu. Terjadinya kenaikan tensi pada kondisi hamil banyak dialami hingga kejadian tersebut meningkat sampai 5-15\% dalam kehamilan. Kondisi Preekalmpsia kehamilan merupakan salah satu penyumbang tertinggi morbiditas dan mortalitas. Angka Kejadian preeklampsia berdasarkan data dari WHO bahwa merupakan angka kejadian di dunia yang cukup tinggi, yaitu sebanyak 861 dari 96.494 ibu hamil dan eklampsia sebanyak 862 dari 96.497 ibu hamil .$^{1}$ AKI mengalami peningkatan dari tahun 2007 sebesar 228 / 100.000 kelahiran hidup menjadi 359/ 100.000 kelahiran hidup, padahal Indonesia 
menargetkan terjadinya penurunan AKI menjadi 102 / 100.000 kelahiran hidup di Tahun 2015. Pada tahun 2014 ada penurunan AKI di daerah Jawa Timur sehingga merupakan prestasi yang baik dengan angka 93,52 sehingga sudah cukup berada di bawah target MDGs di tahun 2015. Tetapi Jawa Timur apabila dilihat dari angka absolut provinsi Jawa Timur masih masuk didalam 5 besar provinsi yang menyumbang angka kematian terbesar atau 50\% Angka Kematian Ibu di Indonesia diantaranya adalah Jawa Barat, Jawa Tengah, Jawa Timur, Sumatera Utara, Banten). Penyumbang Angka Kematian Ibu terbanyak dari provinsi Jawa Timur penyumbangnya adalah kota Surabaya dengan didapatkan 567 kematian Ibu dengan (39 kematian). Dari data diatas, dapat disimpulkan bahwa penurunan angka kematian Ibu yang dilakukan di Jawa Timur akan memberikan dampak besar terhadap penurunan angka kematian Ibu secara Nasional.

Kehamilan merupakan proses fisiologis yang dialami seorang wanita. Proses fisiologi tersebut terkadang dapat diikuti kondisi patologis yang mengancam keadaan ibu dan janin . ${ }^{1}$ Salah satu kondisi patologis dalam kehamilan yang bisa berdampak pada kematian maternal neonatal adalah preeklampsia. Kejadian preeklampsia adalah kondisi ibu hamil usia kehamilan 20 minggu yang mengalami tekanan darah tinggi dimana apabila tidak ditangani dapat membahayakan ibu dan bayi yang bisa menyebabkan kematian ibu dan janin. 2 Preeklampsia ditandai dengan kenaikan tekanan darah atau yang disebut sebagai hipertensi (tekanan darah sistol $\geq 140 \mathrm{mmHg}$ atau tekanan darah diastol $\geq 90 \mathrm{mmHg}$ ) yang disertai proteinuria ( $\geq 300 \mathrm{mg} / \mathrm{dl}$ dalam urin tampung 24 jam) pada usia kehamilan lebih dari 20 minggu atau segera setelah persalinan. ${ }^{3}$ Hingga saat ini penyebab pasti dari preeklampsia belum diketahui, diduga usia dan paritas merupakan beberapa factor yang dapat mempengaruhinya .

Angka Kejadian Preeklampsia-eklampsia tahun 2014 di Jawa Timur adalah 29,9\%, sedangkan perdarahan $26,12 \%$ yang merupakan penyumbang Angka Kematian Ibu terbanyak. Dua fenomena tersebut telah lama menjadi penyebab utama kematian Ibu namun tetap menjadi masalah hingga saat ini.Berbagai strategi dan kebijakan dari pemerintah pusat, pemerintah daerah, dinas kesehatan dan beberapa instansi terkait telah dilakukan namun belum cukup untuk menurunkan kematian akibat kedua penyebab ini. Beberapa masalah yang juga sering terjadi di lapangan adalah banyaknya variasi prosedur dan protokol. Pelaksana pada pelayanan fasilitas kesehatan tingkat primer dan tingkat lanjut diantaranya para bidan, dokter umum, hingga dokter spesialis banyak menimbulkan kebingungan dalam penatalaksanaannya.

Pre-eklampsia merupakan suatu penyakit yang diderita ibu hamil dimana setiap negara angka kejadian berbeda - beda. Kejadian Preeklampsia banyak terjadi di negara berkembang dibandingkan pada negara maju. Penyebabnya adalah pada negara maju perawatan prenatalnya lebih baik, modern dan lebih lengkap. Kejadian preeklampsia dapat di pengaruhi oleh paritas, ras, faktor genetik dan lingkungan. Kejadian Preeklampsia lebih banyak terjadi pada kehamilan yang primigravida, sedangkan pada kondisi multigravida lebih berkaitan dengan penyakit hipertesi kronis, diabetes milletus dan penyakit ginjal.$^{4}$

Preeklampsia adalah penyakit yang terjadi pada kehamilan dengan gejala klinis berupa peningkatan tekanan darah dan proteinuria yang timbul akibat vasospasme dan aktivasi endotel saat usia kehamilan di atas 20 minggu. Dalam kehamilan, pre eklampsia adalah salah satu penyulit yang mampu menyebabkan kesakitan, kecacatan jangka panjang, serta kematian pada ibu, janin dan neonatus. ${ }^{5}$

Penelitian ini dilakukan untuk menentukan apakah terdapat hubungan antara usia dan paritas dengan kejadian preeklampsia di RSD Balung Jember.

\section{METODOLOGI}

Metode Penelitian ini adalah penelitian kuantitatif dengan menggunakan pendekatan cross sectional yaitu mengamati populasi atau sampel satu kali saja pada saat yang sama ${ }^{6}$ Studi penelitian adalah jenis penelitian korelasi yang digunakan untuk membandingkan antara hasil pengukuran dua variabel yang berbeda untuk 
menentukan apakah ada hubungan antara dua variabel tersebut. ${ }^{7}$

Penelitian ini dilakukan untuk mengetahui hubungan paritas dan usia terhadap kejadian preeklampsia.

Tempat pelaksanaan penelitian ini di RSD Balung Jember. Adapun Populasi kasus penelitian ini adalah seluruh kasus ibu hamil dengan preeklampsia yang terjadi pada tahun 2019 mulai bulan januari sampai desember di RSD Balung sebanyak 3594 dan ditentukan sample dalam penelitian sebanyak 97 responden, menggunakan tekhnik pengambilan sampling non random sampling dengan cara purposive sampling. Kriteria Inklusi :Ibu hamil yang mengalami tanda- tanda preklampsia di RSD Balung pada tahun 2019. Kriteria Eksklusi : Ibu yang mengalami kegawat daruratan obstetric selain preeklampsia.

Variabel penelitian ini adalah usia ibu hamil dan paritas adalah termasuk variabel independen, sedangkan variabel dependent adalah kejadian preekalmpsia. Alat ukur berupa data dalam rekam medis. Untuk menganalisa data pada penelitian ini menggunakan Analisa Bivariate karena terdapat dua variabel yang diduga berhubungan atau berkorelasi. Analisis data pada penelitian ini menggunakan Chi Square

\section{HASIL DAN PEMBAHASAN}

\section{Hasil}

a. Distribusi Frekuensi responden berdasarkan usia ibu hamil dan bersalin di RSD Balung tahun 2019

Tabel 1. Distribusi Frekuensi responden berdasarkan usia ibu hamil dan bersalin di RSD

Balung tahun 2019

\begin{tabular}{lccc}
\hline Usia & Kategori & Jumlah & Frekuensi \\
\hline $20-35$ th & $\begin{array}{r}\text { Tidak } \\
\text { berisiko }\end{array}$ & 46 & $47 \%$ \\
$\begin{array}{l}\text { B } 20 \text { dan }> \\
35 \text { th }\end{array}$ & Berisiko & 51 & $53 \%$ \\
\hline Jumlah & & 97 & $100 \%$ \\
\hline
\end{tabular}

b. Distribusi Frekuensi responden berdasarkan paritas ibu hamil dan bersalin di RSD Balung tahun 2019.
Tabel 2. Distribusi Frekuensi responden berdasarkan paritas ibu hamil dan bersalin di RSD Balung tahun 2019

\begin{tabular}{llcc}
\hline Paritas & Kategori & Jumlah & Frekuensi \\
\hline G1 & Primigravida & 66 & $68 \%$ \\
\hline & & & \\
G1 - G4 & Multigravida & 20 & $21 \%$ \\
G5 lebih & Grandemulti & 11 & $11 \%$ \\
\hline Jumlah & & 97 & $100 \%$ \\
\hline
\end{tabular}

c. Distribusi Frekuensi responden berdasarkan pre eklampsia ibu hamil dan bersalin di RSD Balung tahun 2019.

Tabel 3. Distribusi Frekuensi responden berdasarkan pre eklampsia ibu hamil dan bersalin di RSD Balung tahun 2019

\begin{tabular}{llcc}
\hline Pre eklampsia & Kategori & Jumlah & Frekuensi \\
\hline & $\begin{array}{l}\text { Pre eklampsia } \\
\text { ringan }\end{array}$ & 23 & 23.7 \\
& $\begin{array}{l}\text { Pre eklampsia } \\
\text { berat }\end{array}$ & 74 & 76.3 \\
\hline Jumlah & Total & 97 & 100.0 \\
\hline
\end{tabular}

d. Distribusi Frekuensi responden berdasarkan paritas ibu hamil dan bersalin terhadap kejadian Preeklampsia di RSD Balung tahun 2019.

Tabel 4. Distribusi Frekuensi responden berdasarkan paritas ibu hamil dan bersalin terhadap kejadian Preeklampsia di RSD Balung tahun 2019

\begin{tabular}{ccccc}
\hline \multirow{2}{*}{ Paritas } & \multicolumn{4}{c}{ Preeklampsia } \\
\cline { 2 - 5 } & $\begin{array}{c}\text { Preeklampsia } \\
\text { Ringan }\end{array}$ & $\begin{array}{c}\text { Preeklampsia } \\
\text { Berat }\end{array}$ \\
\cline { 2 - 5 } & (n) & $\%$ & (n) & $\%$ \\
\hline Primigravida & 15 & $15,5 \%$ & 51 & $52,6 \%$ \\
Multigravida & 2 & $2,1 \%$ & 18 & $18,6 \%$ \\
$\begin{array}{c}\text { Grandemultipa } \\
\text { ra }\end{array}$ & 6 & $6,2 \%$ & 5 & $5,2 \%$ \\
\hline Total & 23 & $23,8 \%$ & 74 & $76,4 \%$ \\
\hline
\end{tabular}


e. Distribusi Frekuensi responden berdasarkan Usia ibu hamil dan bersalin terhadap kejadian Preeklampsia di RSD Balung tahun 2019.

Tabel 5. Distribusi Frekuensi responden berdasarkan Usia ibu hamil dan bersalin terhadap kejadian Preeklampsia di RSD Balung tahun 2019

\begin{tabular}{lcccc}
\hline \multirow{2}{*}{ Usia } & \multicolumn{3}{c}{ Preeklampsia } \\
\cline { 2 - 5 } & $\begin{array}{c}\text { Preeklampsia } \\
\text { Ringan }\end{array}$ & \multicolumn{2}{c}{$\begin{array}{c}\text { Preeklampsia } \\
\text { Berat }\end{array}$} \\
\cline { 2 - 5 } & (n) & $\%$ & (n) & $\%$ \\
\hline Beresiko & 6 & $6,2 \%$ & 40 & $41,2 \%$ \\
\hline $\begin{array}{l}\text { Tidak } \\
\text { beresiko }\end{array}$ & 17 & $17,5 \%$ & 34 & $35,1 \%$ \\
\hline Total & 23 & $23,7 \%$ & 74 & $76,3 \%$ \\
\hline
\end{tabular}

\section{Distribusi Frekuensi responden berdasarkan usia ibu hamil dan bersalin di RSD Balung tahun 2019}

Berdasarkan hasil penelitian hubungan usia dan paritas terhadap kejadian preeklampsia di RSU Balung tahun 2019 didapatkan hasil bahwa usia mempunyai hubungan yang signifikan terhadap kejadian preeklampsia nilai $\mathrm{p}<0.05$. Hasil dari penelitian yang telah dilakukan menggunakan uji chi-square didapatkan nilai pearson chi-square 0,019 dan nilai $p=0,000<0,05$ dari hasil tersebut Ho ditolak dan Ha diterima. Dengan demikian maka dapat ditarik kesimpulan bahwa ada hubungan yang signifikan antara faktor usia dengan resiko terjadinya preeklampsia, dengan demikian diharapkan kehamilan di usia reproduktif yang sehat pada usia 20-35 tahun. Penyumbang Angka Kematian Ibu dan Bayi yang paling rendah adalah kehamilan dan persalinan pada usia antara 20-29 tahun, Sedangkan usia ibu 16 tahun dalam arti kurang dari 20 tahun terjadi peningkatan resiko terjadinya preeklampsi, umur $>35$ berada pada resiko tinggi dan $>40$ mempunyai resiko sangat tinggi. ${ }^{8}$

Penelitian ini menemukan proporsi ibu yang berusia dalam kategori usia risiko tinggi $(<$ 20 tahun dan > 35 tahun) dan menderita preeklampsia 5.588 kali lebih banyak daripada yang tidak menderita preeklampsia, dibandingkan dengan ibu yang berusia dalam kategori usia risiko rendah (20 - 35 tahun). Berdasarkan analisis statistik menggunakan uji chi square, ditemukan adanya hubungan yang signifikan antara usia ibu dengan kejadian preeklampsia. Maknanya, ibu yang berusia < 20 tahun dan > 35 tahun mempunyai kecenderungan untuk mengalami preeklampsia dibandingkan dengan ibu yang berusia $20-35$ tahun. Penelitian sebelumnya juga mendapatkan bahwa terdapat hubungan $(p=0,00)$ antara ibu yang memiliki usia pada kategori risiko tinggi dengan kejadian preeklampsia dan nilai OR sebesar 3,73.

Pada penelitian lain juga didapatkan bahwa ibu yang berusia dalam kategori usia risiko tinggi memiliki risiko 5,089 kali mengalami preeklampsia dibandingkan dengan ibu yang berusia dalam kategori usia risiko rendah. Preeklamsia adalah kumpulan gejala yang timbul pada ibu hamil, bersalin dan dalam masa nifas. Gejala klinis berupa hipertensi dan proteinuria yang timbul karena kehamilan akibat vasospasme dan aktivasi endotel saat usia kehamilan di atas 20 minggu. ${ }^{9}$

Salah satu penyulit dalam kehamilan adalah Preeklampsia yang bisa menyebabkan terjadinya sakit berat, kecacatan jangka panjang, mortalitas dan mordibitas. Banyak penelitian yang menunjukkan dan membuktikan bahwa angka kejadian preeklampsia ini cukup tinggi. Penelitian yang dilakukan Putri (2020) di RSD Kalisat Jember dengan judul Determinan Kejadian Preeklampsia di RSD Kalisat Jember mendapatkan hasil dengan analisis Chi Square 0,037 yang mempunyai arti bahwa ada pengaruh usia terhadap kejadian preeklampsia. Faktor penyebab terjadinya adalah karena banyak faktor diantaranya adalah fator usia dan paritas ibu. Usia yang dianjurkan seorang wanita dalam bereproduksi adalah usia sehat reproduktif $20-$ 35 tahun. Usia yang sehat dalam bereproduksi adalah merupakan periode untuk hamil dan melahirkan yang paling aman dikarenakan pada usia tersebut risiko terjadinya komplikasi selama kehamilan dan persalinan lebih kecil. Sedangkan usia rentan yang memiliki risiko tinggi untuk mengalami komplikasi selama kehamilan dan persalinan adalah usia di bawah 20 tahun dan di atas 35 tahun. Perkembangan ukuran uterus belum 
berkembang secara sempurna dan belum mencapai ukuran yang normal untuk sebuah kehamilan, sehingga rentan sekali terjadi gangguan kehamilan seperti kasus preeklampsi pada usia $<20$ tahun. ${ }^{10}$ Pada usia tersebut rentan terjadi abortus karena alat-alat reproduksi belum berkembang secara matang. ${ }^{11}$ Sedangkan usia > 35 tahun di mana usia reproduktif sudah terlewati sehingga yang terjadi adalah proses degeneratif yang mengakibatkan perubahan struktural dan fungsional pada pembuluh darah perifer yang bisa menimbulkan perubahan tekanan darah, sehingga lebih rentan mengalami preeclampsia. Penelitian yang dilakukan didapatkan hubungan antara usia $<20$ tahun dengan kejadian preeklampsia, namun tidak terdapat hubungan antara usia > 35 tahun dengan kejadian preeklampsia. ${ }^{12}$

Usia kurang dari 20 tahun disamping dari segi perkembangan alat-alat reproduksi belum sepenuhnya berkembang secara optimal, perkembangan yang lain adalah belum matang dalam menghadapi beban moril dan emosional. ${ }^{11}$

Ibu dengan usia lebih 35 tahun mudah untuk terkena preeklampsia. ${ }^{13}$ Pada proses menua terjadi mutasi gen sehingga resiko preekalmsia meningkat seiring dengan paritas serta usia. ${ }^{14}$

Proses kehamilan serta persalinan sangat dipengaruhi oleh usia. Usia wanita kurang dari 20 tahun potensi besar sekali terjadinya abortus, sama halnya dengan wanita yang usianya lebih dari 35 tahun. Kejadian adanya kehamilan pada usia yang rentan seperti itu, apabila mengalami abortus bisa menyebabkan terjadinya kemtian maternal dan neonatal. ${ }^{15}$ Angka kejadian Preeklampsia pada usia lebih dari 35 tahun sebanyak 58,1\%. ${ }^{16}$

\section{Distribusi Frekuensi responden berdasarkan paritas ibu hamil dan bersalin di RSD Balung tahun 2019}

Berdasarkan hasil penelitian Hubungan usia dan paritas terhadap kejadian preeklampsia di RSU Balung 2019 didapatkan hasil bahwa usia mempunyai hubungan yang signifikan terhadap kejadian preeklampsia nilai $\mathrm{p}<0.05$. Berdasarkan dari data penelitian Tabel 2 menunjukkan bahwa persentase data paritas ibu dengan kejadian preeklampsia ibu yang beresiko adalah ibu dengan kondisi primigravida sebanyak 66 kasus (68 $\%)$,pada paritas tidak beresiko (multigravida) yaitu sebanyak 20 orang (21\%) sedangkan pada grandemultipara sebanyak 11 orang (11\%). Hasil dari penelitian yang telah dilakukan menggunakan uji chisquare didapatkan nilai pearson chi-square 0,019 dan nilai $\mathrm{p}=0,000<0,05$ dari shasil tersebut Ho ditolak dan Ha diterima maka dapat disimpulkan bahwa ada pengaruh yang signifikan antara faktor paritas dengan resiko terjadinya preeklampsia, hasil tersebut dimungkinkan masih banyak paritas responden yang memiliki paritas ideal (multigravida) hal tersebut membenarkan hasil penelitian ini.

Kejadian Preeklampsia banyak terjadi pada kasus Pada primigravida yang memiliki kecenderungan terjadi dua kali lipat lebih besar. ${ }^{12}$ Preeklampsia lebih sering terjadi pada kehamilan pertama dibandingkan dengan kehamilan berikutnya. Penyebab dari kejadian ini adalah pada primigravida pembentukan blocking antibodies terhadap antigen plasenta belum berkembang sempurna, semakin sempurna pada kehamilan berikutnya. ${ }^{14}$ Kasus preeklampsia lebih potensial besar terjadi pada primigravida diibandingkan pada multigravida karena preeklampsia biasanya timbul pada wanita yang pertama kali terpapar vilus korion. Hal ini terjadi karena pada wanita tersebut mekanisme imunologik pembentukan blocking antibody yang dilakukan oleh HLA-G ( human leukocyte antigen G) terhadap antigen plasenta belum terbentuk secara sempurna, sehingga proses implantasi trofoblas ke jaringan desidual ibu menjadi terganggu. ${ }^{17}$ Stres mungkin sekali dialami Primigravida dalam menghadapi persalinan, dimana stres akan menstimulasi tubuh untuk memproduksi kortisol. Peningkatan pada tekanan darah dan curah jantung merupakan akibat dari Efek kortisol yang meningkatkan respon simpatis. 18

\section{SIMPULAN DAN SARAN}

Kesimpulan

a. Umur yang banyak mengalami Preeklampsia adalah umur yang beresiko yaitu kurang dari 20 tahun dan lebih dari 35 tahun sebanyak 74 kasus $(76 \%)$.

b. Paritas yang banyak terjadi adalah primigravida dimana masih baru pertama kali hamil sebanyak 66 kasus (68\%). 
c. Ada Hubungan antara Usia dan Paritas dengan kejadian Preeklampsia di RSD Balung Tahun 2019.

\section{Saran}

a. Hasil penelitian ini bisa dijadikan masukan agar pemeriksaan kehamilan dapat dilakukan tidak hanya 4 kali selama kehamilan agar deteksi dini adanya Preeklampsia dapat dilakukan agar komplikasi dapat dicegah .

b. Kejadian Preeklampsia dapat terjadi pada usia yang beresiko, oleh karena itu sebaiknya pernikahan dapat ditunda apabila usia kurang dari 20 tahun dan kehamilan bisa dicegah pada usia lebih dari 35 tahun.

\section{UCAPAN TERIMA KASIH}

Terima kasih kepada semua pihak yang telah membantu terselenggaranya kegiatan penelitian diantaranya STIKES dr. Soebandi Jember dan RSD Balung yang telah memfasilitasi terlaksananya penelitian ini.

\section{REFERENSI}

1. WHO. Maternal Mortality in 2015. 2015.Departement of Reproductive Health and Research WHO.

2. Prawirohardjo, S. Ilmu Kandungan. 2010.akarta: PT Bina Pustaka Sarwono Prawirohardjo.

3. Robert JM, Pearson GD, Cutler JA, Lindheimer MD. Summary of the NHLBI Working Group on Research on Hypertension During Pregnancy. Hypertension in Pregnancy 2003, 22(2).

4. Gafur.A, Nurdin.A, Rahmadhany.S, dan Rahim.M.R). Hubungan Antara Primigravida dengan Preeklampsia. 2012.

5. Robson, Elizabeth S Dan Jason Waugh .Patologi Pada Kehamilan. 2012. Jakarta, :EGC.

6. Qiu, C., Williams, M. A., Calderon-Margalit, R., Cripe, S. M., \& Sorensen, T. K. Preeclampsia risk in relation to maternal mood and anxiety disorders diagnosed before or during early pregnancy. American Journal of Hypertension. 2009,22(4):397-402. https://doi.org/10.1038/ajh.2008.366

7. Arikunto. Prosedur Penelitian. 2010.Rineka Cipta, Jakarta.

8. Mochtar R. Sinopsis Obstetri. Ed. 21. 2013. Penerbit Buku Kedokteran EGC: Jakarta

9. Notoatmojo, S. Metode Penelitian Kesehatan. 2010. Jakarta: Rineka Cipta

10. Cunningham, G.F. et al.. Williams Obstetrics (22nded). 2005. USA: Mc-Graw Hill.

11. Fibriana, A. I. Faktor-faktor Resiko yang mempengaruhi Kematian Maternal (Studi Kasusu di Kabupaten Cilacap). Journal epidimiologi pasca Sarjana Universitas Diponegoro, 2016, 4(1):4-15.

12. Manuaba, I. A. C. 2010. Penuntun Diskusi Obstetri dan Ginekologi

13. Gunawan, S. .Reproduksi Kehamilan dan Persalinan. 2010. CV Graha

14. Suwanti, E. Hubungan Kualitas perawatan Kehamilan dan Kualitas Pertolongan Persalinan dengan Kematian Maternal di Kabupaten Klaten. Tesis. 2015. Yigyakarta. Program Pasca sarjana universitas Gadjah Mada.

15. JNPK-KR.. Asuhan Persalinan Normal dan Inisisasi Menyusui Dini. 2009. Jakarta : JNPK-KR

16. Bahiyatun. Buku ajar Asuhan Kebidanan Nifas Normal. 2009. Jakarta; EGC

17. Yeyeh, R. Asuhan Kebidanan 4 Patologi. 2010. Jakarta: CV Trans Info Media

18. Aeni, N. Faktor Resiko kematian Ibu. Journal kesehatan Masyarakat Nasional. 2013, 17 (2):453459 